\title{
African violet (Saintpaulia ionantha H. Wendl.): classical breeding and progress in the application of biotechnological techniques
}

\author{
Jaime A. Teixeira da Silva', Yaser Hassan Dewir ${ }^{2,3}$, Adhityo Wicaksono ${ }^{4}$, \\ Leela Sahijram ${ }^{5}$, Haenghoon Kim ${ }^{6}$, Songjun Zeng ${ }^{7}$, \\ Stephen F. Chandler ${ }^{8}$, Munetaka Hosokawa ${ }^{9}$

\begin{abstract}
${ }^{1}$ P.O. Box 7, Miki-Cho Post Office, Ikenobe 3011-2, Kagawa-Ken, 761-0799, Japan
${ }^{2}$ Plant Production Department, P.O. Box 2460, College of Food \& Agriculture Sciences King Saud University, Riyadh 11451, Saudi Arabia

${ }^{3}$ Department of Horticulture, Faculty of Agriculture, Kafrelsheikh University, Kafr El-Sheikh 33516, Egypt

${ }^{4}$ Laboratory of Paper Coating and Converting, Centre for Functional Material

Åbo Akademi University, Porthaninkatu 3, 20500 Turku, Finland

${ }^{5}$ Division of Biotechnology, Indian Council of Agricultural Research (ICAR) - Indian Institute of Horticultural

Research, Hessaraghatta Lake Post, Bangalore, Karnataka, 560 089, India

${ }^{6}$ Department of Well-being Resources, Sunchon National University, Suncheon, 540-742, South Korea

${ }^{7}$ Guangdong Provincial Key Laboratory of Applied Botany, South China Botanical Garden, the Chinese Academy of Sciences, Guangzhou, 510650, P.R. China ${ }^{8}$ School of Applied Sciences, RMIT University, Bundoora, Victoria, VIC 3083, Australia

${ }^{9}$ Graduate School of Agriculture, Kyoto University, Sakyo-ku, Kyoto 606-8502, Japan
\end{abstract}

\begin{abstract}
As a result of its domestication, breeding and subsequent commercialization, African violet (Saintpaulia ionantha $\mathrm{H}$. Wendl.) has become the most famous and popular Saintpaulia species. There is interest in producing cultivars that have increased resistance to pests and low temperature, in the introduction of novel horticultural characteristics such as leaf shape, flower colour, size and form, and in improved productivity and enhanced flower duration in planta. In African violet, techniques such as the application of chemical mutagens (ethylmethanesulfonate, $N$-nitroso- $N$-methylurea), radiation (gamma $(\gamma)$-rays, $\mathrm{X}$-rays, carbon ion beams) and colchicine have been successfully applied to induce mutants. Among these techniques, $\gamma$ radiation and colchicine have been the most commonly applied mutagens. This review offers a short synthesis of the advances made in African violet breeding, including studies on mutation and somaclonal variation caused by physical and chemical factors, as well as transgenic strategies using Agrobacterium-mediated transformation and particle bombardment. In African violet, Agrobacterium-mediated transformation is affected by the Agrobacterium strain, selection marker, and cutting-induced wounding stress. Somaclonal variation, which arises in tissue cultures, can be problematic in maintaining true-to-type clonal material, but may be a useful tool for obtaining variation in flower colour. The only transgenic African violet plants generated to date with horticulturally useful traits are tolerant to boron (heavy metal) stress, or bear a glucanase-chitinase gene.
\end{abstract}

Key words: Agrobacterium-mediated transformation, Gesneriaceae, mutation, particle bombardment, somaclonal variation, transgenic

Corresponding authors

E-mail: 1jaimetex@yahoo.com, ${ }^{2}$ ydewir@hotmail.com, ${ }^{4}$ adhityo.wicaksono@gmail.com, ${ }^{5}$ leelas@iihr.res.in,

${ }^{6}$ cryohkim@sunchon.ac.kr, ${ }^{7}$ zengsongjun@scib.ac.cn, ${ }^{8}$ schandler230@gmail.com, ${ }^{9}$ mune@kais.kyoto-u.ac.jp. 


\section{INTRODUCTION}

African violet (Saintpaulia ionantha H. Wendl.; Gesneriaceae) is the most famous and popular Saintpaulia species. It has been domesticated, bred and commercialized, and can be vegetatively propagated fairly easily (Teixeira da Silva et al. 2016a). A historical text by Tsukamoto et al. (1982) indicates how the cultivation of Saintpaulia originally started in Europe, but its development as a horticultural plant took place in the United States after World War II. Tsukamoto et al. (1982) also noted that by 1981 there were about 20 species in the genus Saintpaulia, although The Plant List (2017) indicates that there are currently 25 species, including accepted, synonymic and unresolved species.

This review offers a short synthesis of advances made in mutation and somaclonal variation caused by physical and chemical factors, as well as transgenic strategies using Agrobacteriummediated transformation and particle bombardment. Classical breeding has the ability to transfer a desired trait into different cultivars of any plant species, but if one or more of the parent cultivars used in cross-breeding are poorly adapted, then a back-crossing strategy needs to be implemented to recover the elite type. Moreover, poor combining ability of some parental genotypes may occur and doubled (i.e., multi-whorled) flowers do not produce male or female organs. For example, aromatic rice varieties have poor combining ability, and crossbreeding with non-aromatic varieties will lead to a decrease in aroma and quality (Bourgis et al. 2008). Under such circumstances, the induction of mutations can be advantageous to produce cultivars with desired traits within defined germplasm pools. Mutation breeding thus offers a solution to difficulties encountered in classical breeding. For example, if genes conferring undesirable characters are tightly linked to genes controlling desirable traits, then induction of mutations may result in a cross-over event or isolation of an independent mutation for the desired trait (van Harten 2007). Mutation breeding may be the only acceptable way of classically increasing variability in plant species that do not produce seeds (Ahloowalia and Maluszynski 2001), and to develop novel colours and variations in vegetatively propagated ornamental plant species (Broertjes and van Harten 1988, Datta and Teixeira da Silva 2006, Kondo et al. 2009). Thus, mutation breeding is considered to be a valuable conventional breeding strategy.
Mutation techniques have made significant contributions in ornamental crop improvement. Hundreds of mutant cultivars have been officially released for various traits in horticulture, including the colour and shape of flowers and fruits, and flesh colour (Datta and Teixeira da Silva 2006). However, plant breeders are under continuous pressure to improve existing cultivars or to develop new ones. Therefore, there is a need for newer alternatives or technologies that, when combined with conventional breeding methods, can help create greater variability with desirable novel traits, while reducing the time taken to do so. In vitro culture of plant cells and organs generates genetic variability ('somaclonal variation') resulting in 'somaclones' (regenerated plants that are not trueto-type) which can be used in sexual hybridisation for introgression of desirable alien genes into crop species, or to generate variants of a commercial cultivar at a high frequency without hybridizing it to other genotypes (Larkin and Scowcroft 1981). Ever since the first formal report of morphological variants in sugarcane plants produced in vitro in 1971, numerous somaclonal variations have been reported in several horticultural crops (Krishna et al. 2016). Somaclonal variation manifests itself as qualitative or quantitative phenotypic changes, sequence changes, and gene activation/silencing (Kaeppler et al. 2000). Epigenetic changes occur via changes in DNA methylation patterns, activation of quiescent transposable elements (TEs) or retrotransposons (Duncan 1997, Huang et al. 2009). In important horticultural crops, DNA methylation patterns are highly variable among regenerants and polymorphisms exist in somaclones (Sahijram 2014, 2015). In African violet, $47 \%$ of somaclonal variants from in vitro cultures did not flower. No variation was seen in flower colour in the remaining flowering plants (Jain 1993a, 1993b, 1997a, 1997b), although these studies did not assess genetic alterations.

It is possible to induce variation in flower colour and introduce several other novel traits to ornamental plants using somaclonal variation. Often, a plant regeneration system, particularly callus-mediated plant regeneration, introduces variations that may be heritable (Krishna et al. 2016). The concentration and combination of plant growth regulators (PGRs), as well as subculture frequency and duration, also result in a higher frequency of variation (Matsuda et al. 2014). TE transposition and a combination of factors such as colchicine, gamma $(\gamma)$-rays, ion-beams, and PGRs, 
may serve as a good set of tools for expanding variations in flower colour in African violet.

\section{Classical breeding}

\section{Self-pollination}

Saintpaulia flowers are zygomorphic with two upper and three lower lobes. The upper two lobes are smaller than the lower ones. Saintpaulia has a very short corolla tube and yellow protruding anthers that are probably associated with buzz pollination (Harrison et al. 1999). The anthers of Saintpaulia have only one chamber, the flowers have a distinct disk, the style and stigma usually have the same colour as the petals, and the ovary is exserted slightly to the left or right of the center of the corolla (Harrison et al. 1999). All Saintpaulia species are enantiostylous (the style is strongly deflected to the left or right of the main floral axis), a feature often linked to buzz pollination $S$. ionantha is a protandrous species, and the anthers appear to be full of pollen, even during the pistillate phase. The anthers do not wilt, remain yellow and have thecae and stiffened walls (Vogel 1978). Most Saintpaulia species can hybridize with their congenerics and produce fertile hybrids (Arisumi 1964).

The diploid chromosome number in African violet was indicated by Vazquez et al. (1977), Espino and Vazquez (1981) and Sun et al. (2010) to be $2 n=28$. Farjadi-Shakib et al. (2012) were of the opinion that since African violet had tiny chromosomes with a propensity for sticking together and a centromere difficult to distinguish, the diploid chromosome number in this species was incorrectly described as $2 \mathrm{n}=2 \mathrm{x}=28$ (Sugiura 1936, Adisorn 2004). More detailed cytological analyses indicated that the diploid chromosome number was $2 \mathrm{n}=2 \mathrm{x}=30$ (Ehrlich 1956, FarjadiShakib et al. 2012), and $2 n=60$ for the tetraploid hort. var. 'Ionantha Amazon' (Ehrlich 1958), with a total genome length of $29.995 \mu \mathrm{m}$, and a ratio of the longest to the smallest chromosome of 2.77 (Farjadi-Shakib et al. 2012). Using flow cytometry, Loureiro et al. (2007) determined that the nuclear DNA content (i.e., genome size) of diploid S. ionantha was $2 \mathrm{C}=1.5 \mathrm{pg}$.

Spontaneous self-pollination has been reported to occur frequently in some commercial African violet cultivars through an abnormal mode of flower development in which the stigma grows into the anther (Anonymous 2002). Self-fertilization and mating between close relatives in small populations may lead to inbreeding depression (Charlesworth and Charlesworth 1987, Kolehmainen and
Mutikainen 2006). Kolehmainen et al. (2010) investigated inbreeding depression in 12 populations of a threatened, endemic African violet, S. ionantha ssp. grotei, using one microsatellite locus, and concluded that inbreeding occurred frequently and led to significant inbreeding depression.

\section{Interspecific crosses}

Saintpaulia is likely to predominantly outcross because it is pollinated by flying insects and because the flowers have two different stylar morphs (i.e., enantiostyly), which has been shown to promote cross pollination (Jensson and Barrett 2002). Crossing experiments have shown that the majority of Saintpaulia taxa can hybridize and that hybrid offspring are fertile (Clayberg 1961, Arisumi 1964). However, Afkhami-Sarvestani et al. (2012a) were unable to produce viable progeny, even using embryo rescue, from intergeneric crosses between Streptocarpus sub-genus Streptocarpella and S. ionantha. Afkhami-Sarvestani et al. (2012b) were able to induce callus after fusing protoplasts.

Arisumi (1967) conducted a large breeding experiment in which he selfed and crossed several clones of Saintpaulia species that had no anthocyanin in their leaf blades, namely, according to the Interagency Taxonomic Information System \& World Checklist of Gesneriaceae, S. amaniensis E. Roberts [now accepted as $S$. ionantha ssp. grotei (Engler) I. Darbysh, taxonomic serial No. (TSN) 832566], S. confusa B. L. Burtt. [now accepted as $S$. ionantha ssp. grotei (Engler) I. Darbysh, TSN 832554], S. difficilis B. L. Burtt. [now accepted as $S$. ionantha ssp. grotei (Engler) I. Darbysh, TSN 832556], S. diplotricha B. L. Burtt. [now accepted as S. ionantha var. diplotricha (B.L. Burtt) I. Darbysh., TSN 832560], S. grandifolia B. L. Burtt. [now accepted as $S$. ionantha ssp. grandifolia (B.L. Burtt) I. Darbysh, TSN 832561], S. grotei Engl. [now accepted as $S$. ionantha ssp. grotei (Engler) I. Darbysh., TSN 832562], and S. magungensis E. Roberts [now accepted as $S$. ionantha ssp. grotei (Engler) I. Darbysh., TSN 832616] (Skog and Boggan 2010, ITIS - available online at: https://www. itis.gov). After germinating seeds and growing seedlings according to Arisumi (1964), Arisumi (1967) determined genetic ratios after assigning the symbols $A$ and $a$, respectively, to dominant and recessive genes for anthocyanin. Arisumi (1967) found that: a) $A$ and $a$ segregated in classic Mendelian ratios; b) S. diplotricha (syn. S. ionantha var. diplotricha) was homozygous recessive (aa), whereas all the other species were heterozygous 
$(A a)$; c) the $A$ gene might control anthocyanin production in L-I, L-II and L-III layers; d) $S$. ionantha 'Snow Prince' and 'Northern Snowflake' had a recessive gene for white flower colour which prevented the formation of anthocyanin anywhere in the plant. Arisumi and Frazier (1968) induced a single chimeric polyploid plant from 29 regenerants after treating leaf cuttings with colchicine.

After intensive breeding over the past century, thousands of cultivated Saintpaulia varieties are mass propagated by the horticulture industry (Baatvik 1993). These cultivars have mainly been bred from two natural species, $S$. ionantha and S. confusa (S. ionantha ssp. grotei) (Baatvik 1993, Eastwood et al. 1998).

\section{Ploidy and polyploidization}

Espino and Vazquez (1981) regenerated polyploid and mixoploid plants from leaf explants using caffeine or colchicine, but no polyploidy was detected in regenerants grown on control medium. More specifically, exposure of leaf explants to basal Murashige and Skoog medium containing 500 or $1000 \mathrm{mg} \mathrm{l}^{-1}$ caffeine for 4-16 days resulted in 2-8\% polyploid plants (including chimeric plants), whereas exposure to $100-200 \mathrm{mg} \mathrm{l}^{-1}$ colchicine resulted in $22-46 \%$ polyploids. Their results were in contrast to the low level of mixoploidy (1-2\%) observed by Broertjes (1974) when petioles and leaves were exposed to colchicine. Winkelmann and Grunewaldt (1995) confirmed that $16 \%$ of regenerants derived from protoplast culture were polyploid (mostly tetraploid). Seneviratne and Wijesundara (2003) applied $0.05 \%$ colchicine for $18 \mathrm{~h}$ to leaves of four unspecified African violet varieties, and succeeded in producing dwarf plants with small, succulent leaves with a short petiole, suitable for use as table-top miniature plants. Bhaskaran et al. (1983) obtained anther-derived plants that were not haploid, but diploid or tetraploid, possibly due to the endomitosis during tissue culture.

\section{Mutation breeding and chimeras}

Periclinal chimeras were observed in pinwheel flowering African violet varieties (Lineberger and Druckenbrod 1985) and several breeding-oriented mutations have been reported in Saintpaulia. Several techniques are available to induce mutations in ornamental plants, including chemical and radiation $(\gamma$ - or X-ray irradiation, ion-beam treatment) or TE activation (Datta and Teixeira da Silva 2006). Sparrow et al. (1960) suggested that chimeras originating from a low percentage of $S$. ionantha mutants $(0.7 \%)$ might be of multicellular origin.

\subsection{Chemical mutagenesis}

Warfield (1973) produced 13\% mutations after treating petioles of leaf cuttings of $S$. ionantha (cultivar not specified) with $0.5 \mathrm{M}$ ethylmethanesulfonate (EMS) for $1 \mathrm{~h}$, including leaf-patterning mutants, leaf colour variants, and dwarf plants. Except at a lethal dose, Kelly and Lineberger (1981) found that thermal neutron irradiation $(250,1000$ and $5000 \mathrm{Rad}$ of thermal neutrons) of cuttings reduced root emergence and induced changes in peroxidase profiles, but did not induce any morphological mutants. By applying $400 \mathrm{mg} \mathrm{l}^{-1} N$-nitroso- $N$-methylurea (NMU) to in vitro leaves (Geier 1983), leaf albinism and mottling could be induced; this could be increased to $50 \%$ when $0.1-1.0 \%$ dimethyl sulfoxide was added. In the same study, exposure to 97.45 or $292.36 \mathrm{mM}$ EMS produced different levels of shoot inhibition and chlorophyll-deficient shoots relative to controls and NMU-treated leaves (Tab. 1). Grunewaldt (1983) observed that as many as $40 \%$ of regenerants from NMU-treated leaf explants showed altered leaf pigmentation. Gaj and Gaj (1996) induced chlorophyll chimerism (variegated leaves) in $100 \%$ of explants when leaves were treated with $5 \mathrm{nM}$ NMU for 1.5 or $2 \mathrm{~h}$. In all of these studies, stable transmission of mutations from one clonal generation to the next was not possible. Leaf blade and petiole cuttings of $S$. ionantha 'Ulery' exposed to thermal neutron irradiation (250-5000 Rad) did not generate any morphologically distinct mutants, although variation in peroxidase levels was observed.

\subsection{Physical mutagenesis (radiation)}

Using an unnamed cultivar, Seneviratne and Wijesundara (2007) reported a change in flower colour pattern (white petals with wide, pink margins) by coupling 15 Gy of $\gamma$ irradiation with a dip treatment of leaves bearing $2.5 \mathrm{~cm}$ long petioles in $0.06 \%$ colchicine for $22.5 \mathrm{~h}$. The same treatment resulted in a change in plant architecture, measured as reduced petiole length $(3.9 \mathrm{~cm}$ vs $8 \mathrm{~cm}$ in the control), reduced leaf surface area (14.7 $\mathrm{cm}^{2}$ vs $34.8 \mathrm{~cm}^{2}$ in the control), smaller flower diameter $(2.1 \mathrm{~cm}$ vs $3.8 \mathrm{~cm}$ in the control) and shorter inflorescence height $(3.7 \mathrm{~cm}$ vs $6.4 \mathrm{~cm}$ in the control). In their experiment, all the plants died after $\gamma$ irradiation of $20 \mathrm{~Gy}$. Wongpiyasatid et al. (2007a, 2007b) tested $\gamma$-ray (0-100 Gy) treatment of leaf cuttings of two unnamed cultivars of African violet (Wongpiyasatid et al. 2007a) or 'Optima Hawaii' (Wongpiyasatid et al. 2007b). The $\mathrm{LD}_{50(60)}$, 
Table 1. Key results from Geier (1983) (modified) showing the impact of $1 \mathrm{~h}$ exposure of two chemical mutagens, $N$-nitroso- $N$-methylurea (NMU) and ethylmethanesulfonate (EMS), on shoot inhibition and production of chlorophylldeficient shoots in 'Rhapsodie 26' at 73 days of treatment

\begin{tabular}{|c|c|c|c|c|}
\hline Treatments & $\begin{array}{l}\text { Rinse }\left(\mathrm{H}_{2} \mathrm{O}\right) \\
(\text { min. })\end{array}$ & $\begin{array}{c}\text { Number of shoots per } \\
\text { explant }\end{array}$ & $\begin{array}{l}\text { Inhibition of shoot } \\
\text { formation (\%) }\end{array}$ & $\begin{array}{c}\text { Chlorophyll-deficient } \\
\text { mutants }(\%)\end{array}$ \\
\hline & & \multicolumn{3}{|c|}{ EMS } \\
\hline Control* & & 43.3 & 0.00 & 0.00 \\
\hline \multirow{2}{*}{$1 \%(97.45 \mathrm{mM})$} & $3 \times 2$ & 17.6 & 59.35 & 1.14 \\
\hline & $3 \times 20$ & 23.8 & 45.03 & 0.84 \\
\hline \multirow{2}{*}{$3 \%(292.36 \mathrm{mM})$} & $3 \times 2$ & 5.6 & 87.99 & 1.92 \\
\hline & $3 \times 20$ & 20.1 & 53.58 & 1.49 \\
\hline & & \multicolumn{3}{|c|}{ NMU } \\
\hline Control & & 38.0 & 0.00 & 0.00 \\
\hline \multirow{2}{*}{$400 \mathrm{mg} \mathrm{l}^{-1}(3.88 \mathrm{mM})$} & $3 \times 2$ & 10.9 & 71.91 & 12.84 \\
\hline & $3 \times 20$ & 19.6 & 49.48 & 8.67 \\
\hline \multirow{2}{*}{$800 \mathrm{mg} \mathrm{l}^{-1}(7.76 \mathrm{mM})$} & $3 \times 2$ & 3.5 & 90.98 & 20.00 \\
\hline & $3 \times 20$ & 7.6 & 80.41 & 18.42 \\
\hline Control & & 51.6 & 0.00 & 0.00 \\
\hline $200 \mathrm{mg} \mathrm{l}^{-1}(1.94 \mathrm{mM})$ & Undefined & 38.3 & 25.78 & 4.44 \\
\hline $400 \mathrm{mg} \mathrm{l}^{-1}(3.88 \mathrm{mM})$ & Undefined & 24.0 & 46.51 & 8.33 \\
\hline $600 \mathrm{mg} \mathrm{l}^{-1}(5.82 \mathrm{mM})$ & Undefined & 9.8 & 81.00 & 14.29 \\
\hline $800 \mathrm{mg} \mathrm{l}^{-1}(7.76 \mathrm{mM})$ & Undefined & 6.0 & 88.37 & 20.00 \\
\hline
\end{tabular}

*No chemical mutagen treatment

which indicates $50 \%$ dead leaves at 60 days after irradiation, was $56 \mathrm{~Gy}$, and the highest frequency of mutation $(18.33 \%$ ) occurred when 60 Gy was applied; irradiation exceeding 80 Gy caused the death of all leaves. Vegetative and floral mutations induced changes in plant canopy width, number of leaves, number of inflorescences per plant, number of flowers per inflorescence, and flower form, colour and size. For example, at $60 \mathrm{~Gy}, 24.9$ leaves/plant were formed versus 20.5 in the control. In a few cases (Wongpiyasatid et al. 2007a), there was conversion from a vegetative meristem into a floral meristem and subsequent formation of an inflorescence in place of leaves. According to Wongpiyasatid et al. (2007a), detached leaves exposed to X-rays and fast neutrons also showed dose-dependent mutagenesis (Broertjes 1968, 1971, 1972). Zhou et al. (2006a, 2006b) irradiated adventitious shoots in vitro with carbon ion beams and X-rays, and found that $49.6 \%$ and $43.3 \%$ of 'Mauve' and 'Indikon' shoots, respectively, were malformed in response to carbon ion beams, but only $3.7 \%$ and $11.3 \%$ following X-ray irradiation.

\section{Somaclonal variation as a result of tissue culture}

In vitro leaf and petiole homogenate cell clusters of $S$. ionantha 'Crimson Frost' were used for studies on somaclonal variation (Paek and Hahn 1999). The resulting plants showed variations in leaf colour ( $67 \%$ of variants) and leaf shape (19\% of variants), but no difference in protein profiles was observed using SDS-PAGE. Semi-double and double flower types were more common than the single flower type, showing $81 \%$ normal (mixed) colour vs. pink, red or white (19\% of variants) (Paek and Hahn 1999). Their results indicate that the use of homogenate cell clusters was not a proper method for true-totype propagation of African violet. In Saintpaulia 'Thamires' (Saintpaulia sp.), flower colour variants in tissue culture-derived regenerants were formed due to the excision of a TE (Sato et al. 2011a, 2011b). Much of the variability seen in micropropagated plants may be either the result of, or may be related to, oxidative-stress damage in plant tissues during in vitro culture (Matsuda et al. 2014). Simply by culturing leaf explants in vitro, Shajiee et al. (2006) were able to induce variegated leaves in a maximum of $0.78 \%$ of regenerants in one of the studied genotypes.

In Saintpaulia, somaclonal variation is considered problematic when clonal (true-to-type) material is desired, as indicated by the studies above, but is also very useful for improving traits. Sato et al. (2011b) identified a $h$ AT superfamily TE (VGsI) in the flavonoid 3', 5' hydroxylase $\left(\mathrm{F3}^{\prime} \mathrm{5}^{\prime} \mathrm{H}\right)$ promoter region and found that when the TE was 


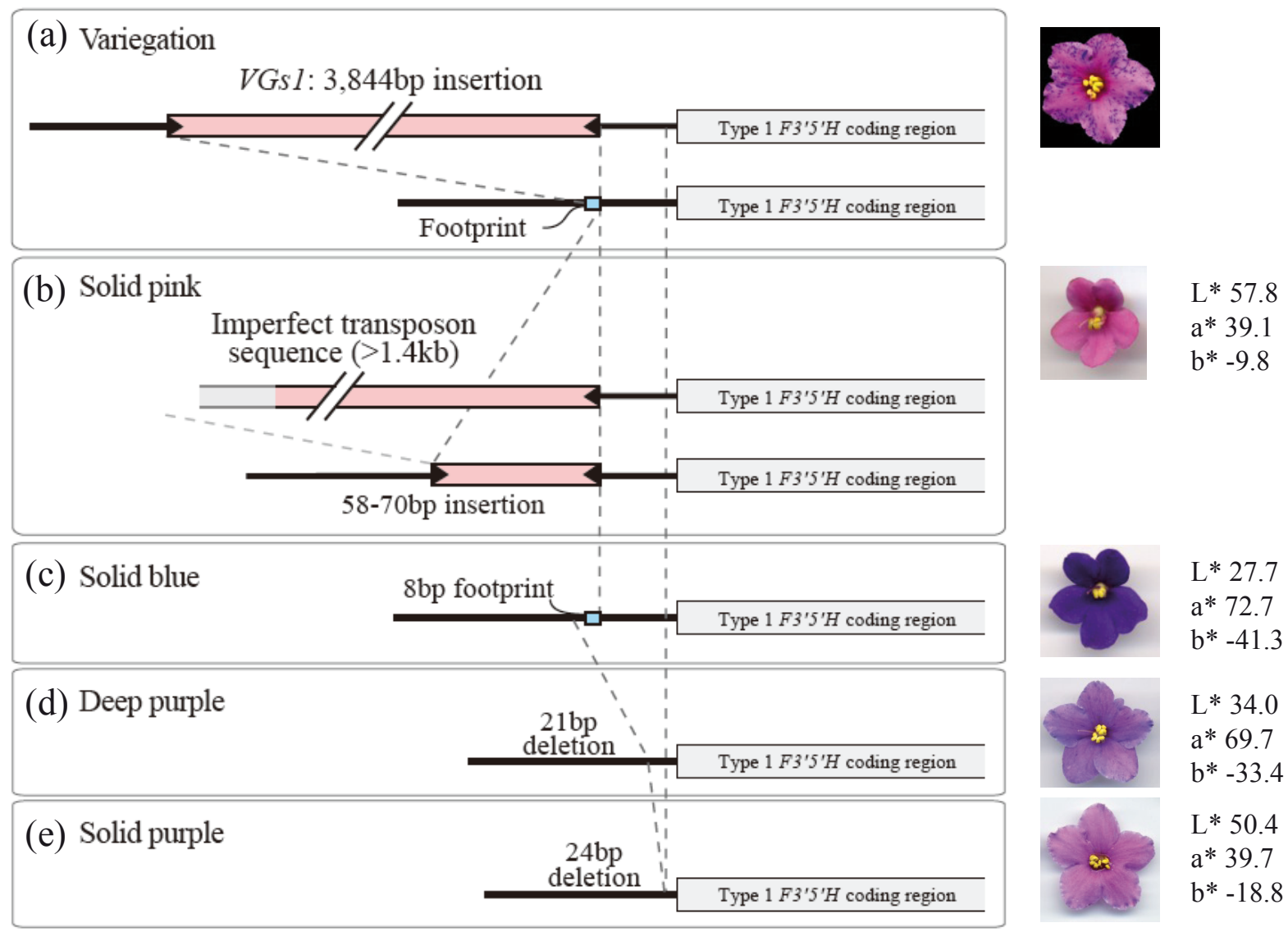

Figure 1. Schematic representation of $F 3^{\prime} 5^{\prime} H$ and its promoter region (not to scale). Variegated individuals (a) have two types of $F 3^{\prime} 5^{\prime} H$ (flavonoid 3',5'-hydroxylase) sequences: one has a 3844-bp insertion and the other appears to have a post-excision sequence (see c). Solid-pink mutants (b) also have two types of sequences: one has imperfect transposon insertion and the other has erratic post-excision sequences varying from 58 to $70 \mathrm{bp}$. Solid-blue mutants (c) have a sequence with an 8-bp footprint. Deep-purple (d) and solid-purple (e) mutants have sequences lacking 21and 24-bp regions, respectively, compared to the solid blue mutant (see: c). Accession numbers (GenBank): transposon VGs1 - AB596833, solid pink - AB596835-AB596837, solid blue - AB596834, deep purple - AB596838, solid purple - AB596839. Figure modified from Sato et al. (2011a,b) and Matsuda et al. (2014). L*, a*, b* - refers to the Hunter colour scale (Hunter 1948)

excised from this region, flower colour changed from pink to purple (Fig. 1). In Saintpaulia 'Thamires', Sato et al. (2011a) concluded that the origin of somaclonal variation could be mainly attributed to 'newly induced mutations'. Matsuda et al. (2014) tried to identify factors involved in the induction of transposition of $V G s l$, and plant growth regulators added to the culture medium were candidate factors for the induction of somaclonal variation.

\section{Molecular breeding}

\section{Molecular and biochemical regulation of flowering}

The genetic control of flower initiation and flower development, and the molecular mechanisms that are responsible for the regulation of these processes have been studied in detail (reviewed in Stewart et al. 2016). Saintpaulia has been included in some of these studies. Wang et al. (2006) isolated two $C Y C$-like genes, SiCYClA and SiCYClB, from zygomorphic and actinomorphic cultivars respectively, of S. ionantha, using mTAIL-PCR. The two SiCYC1A genes contained the entire regulatory domains (i.e., TCP and $\mathrm{R}$ domains) that were functional in establishing floral symmetry, and these were homologous with the Antirrhinum majus CYC gene. Unexpectedly, the two $S i C Y C 1 B$ genes from the actinomorphic cultivar had a sequence identical to genes from the zygomorphic cultivar. Comparative analysis of molecular alterations in CYC-like genes responsible for morphological transformation from zygomorphy to actinomorphy indicated that the two closely related $S i C Y C I A$ and $S i C Y C I B$ genes were perhaps regulated by a common, upstream regulator. Change in this regulator could result in the silencing of both SiCYClA and SiCYClB, thus 
controlling the development of the adaxial and lateral organs in a flower.

Pei et al. (2012) reported that the range of $\mathrm{pH}$ values in cellular sap of the linguoid petal in blue and white flower $S$. ionantha cultivars was 3.0 to 7.0. The $\mathrm{pH}$ value (6.21) of the blue flower cultivar was higher than that of the white flower cultivar ( $\mathrm{pH}$ 3.32) on the first day of flowering and increased when the flowering period was extended from 1 to 20 days. The changes were greater in the white cultivar than in the blue cultivar. On the 20th day of flowering the $\mathrm{pH}$ value was 6.64 in the blue cultivar and 4.21 in the white cultivar.

\section{Genetic modification}

Genetic modification of ornamental plants is an important means of introducing new characters such as modified flower colour, leaf shape or plant architecture (Teixeira da Silva et al. 2016b). The technology for genome editing has progressed considerably in recent years, and using techniques such as CRISPR/Cas9 (Samanta et al. 2016) it is now possible to knock out a specific gene or to target a specific position on the genome for genetic modification. Now in its infancy, artificial chromosome technology offers an opportunity for multiple gene transfer in the future as part of a genetic engineering strategy ( $\mathrm{Yu}$ et al. 2016). It seems that genetic transformation could also help create plants resistant to Melodogyne arenaria Thamesii, a root-knot nematode known to infect the roots of potted S. ionantha plants (Goidanich and Garavini 1959).

\subsection{Transformation of Saintpaulia}

Several researchers have reported the production of transgenic Saintpaulia plants. Kushikawa et al. (2001) succeeded in Agrobacterium-mediated transformation of $S$. ionantha. After testing Agrobacterium strains LBA4404 (plasmid pTOK233), EHA101 (pIG121 hygromycin) and LBA4404 (pIG121 hygromycin), positive results were obtained for LBA4404. In their experiment, a suspension culture of Saintpaulia 'Pink Veil' was exposed to LBA4404 for $48 \mathrm{~h}$, and after 4 months of culture on selection medium containing $50 \mathrm{mg} \mathrm{l}^{-1}$ hygromycin, hygromycin-resistant callus was obtained. Transgenic plants harbouring the gusA gene were confirmed by PCR and Southern blot analysis, although the number of transgenic plants produced and the transformation efficiency were not indicated. No transformants were derived directly from leaves but only via callus. Using the same plasmid constructs as in their 2001 study,
Kushikawa et al. (2002) were able to increase the number of GUS foci by co-cultivating leaf explants with $300 \mu \mathrm{M}$ acetosyringone. Mercuri et al. (2000) obtained transgenic Saintpaulia 'Rhapsody' plants using A. tumefaciens oncogenic strain A281 after infecting petiole slices (3-10 $\mathrm{mm}$ thick), but no plants were recovered from co-cultivated leaves. No success was obtained when the disarmed strain EHA105 was used. In their protocol, 30-min. co-culture with Agrobacterium followed by the culture of explants in the dark on selection medium containing $100 \mathrm{mg} \mathrm{l}^{-1}$ kanamycin resulted in high (90\% of explants) transient GUS gene expression after 3 days, reduced expression (30\% of explants) after 15 days, and no expression after 25 days. The GUS gene was not detected by PCR in all the GUS-positive plants tested, but the nptII gene was detected in Southern blot analysis, suggesting either loss of the transgene, or transgene silencing. Ram and Mohandas (2003) used LBA4404 harbouring pBINAR carrying a glucanase-chitinase gene to transform Saintpaulia 'Sailors Delight' leaves after co-cultivation for $5 \mathrm{~min}$., and following culture in the dark in the presence of $70 \mathrm{mg} \mathrm{l}^{-1}$ kanamycin. A high percentage (75\%) of putative transformants showed a signal for the glucanase gene in Southern blot analysis. Ohki et al. (2009) suggested that Saintpaulia varieties 'Heavens A-calling', 'Kris', and 'New Mexico' leaf explants dipped in a solution of A. tumefaciens (pIG121HM) should be cultured at a minimum of $30 \mathrm{mg} \mathrm{l}^{-1}$ hygromycin for selection. Ye et al. (2014) genetically transformed the AtTIP5;1 gene (a highly expressed Arabidopsis pollen-specific gene related to aquaporin) into the leaves of an unspecified $S$. ionantha cultivar using A. tumefaciens strain GV3101. The authors found that pre-culture for $2 \mathrm{~d}$ on non-selective shoot induction medium, infection for $15 \mathrm{~min}$., coculture for $2 \mathrm{~d}$ with $100 \mu \mathrm{mol} \mathrm{l^{-1 }}$ acetosyringone and selection with $40 \mathrm{~g} \mathrm{l}^{-1}$ hygromycin were the optimal transformation conditions. After screening with PCR and RT-PCR, 17 transformed plants containing the AtTIP5;1 transgene were obtained. Transformed AtTIP5;1 plants showed improved tolerance to boron stress.

In addition to the Agrobacterium strain and the selection marker used, the stress caused by cutting the explants is important for Agrobacterium infection since $S$. ionantha plants are very sensitive to local wounding of leaves (Yang et al. 2002). Wounding of leaves induces a hypersensitive state in explants, such as the leaves of the species of the Acanthaceae and Gesneriaceae, including 


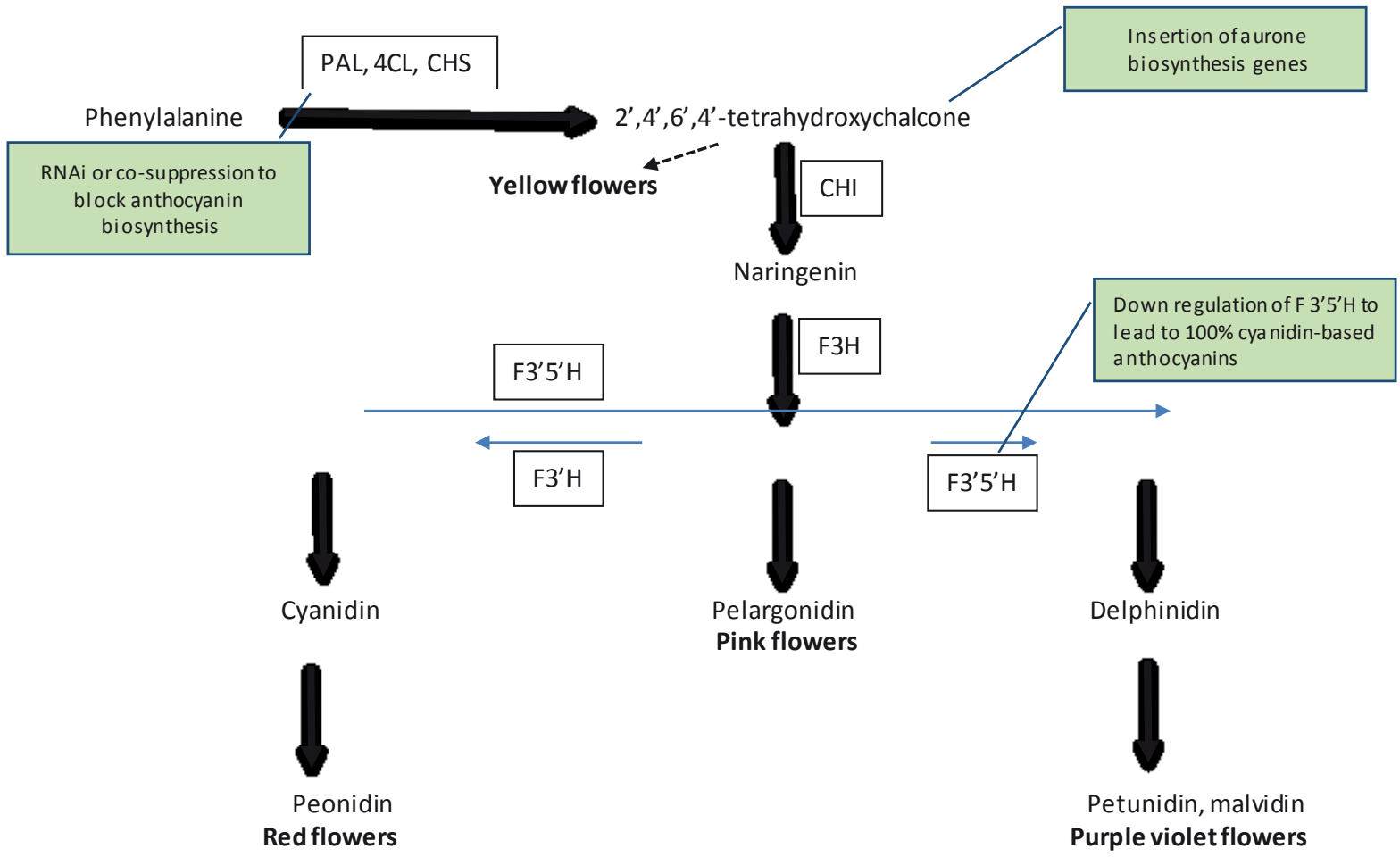

Figure 2. Schematic representation of the flower pigment biosynthesis pathways in Saintpaulia showing (filled text boxes with grey-light blue) the points at which genetic modification could be applied. In this simplified diagram, key enzymes are abbreviated as follows: PAL - Phenylalanine ammonia lyase, $4 \mathrm{CL}$ - 4-Coumarate-CoA ligase, CHS - chalcone synthase, $\mathrm{CHI}$ - chalcone isomerase, $\mathrm{F} 3 \mathrm{H}$ - flavanone 33-hydroxylase, $\mathrm{F} 3$ 'H - flavonoid 3'-hydroxylase, F3'5'H - flavonoid 3',5'-hydroxylase

Saintpaulia sp., resulting in the browning of unwounded areas within $30 \mathrm{~min}$. as a result of secondary wounding (Yang et al. 2002, 2003, 2006). Therefore, leaf wounding, such as that caused during the preparation of leaf segments, may have a negative effect on Agrobacterium infection. Ghorbanzade and Ahmadabadi (2015) used particle bombardment to genetically transform a local Iranian cultivar of African violet with the GUS gene. An endochitinase gene was then introduced and stable integration was confirmed by PCR and RT-PCR in 4 out of 7 lines.

\subsection{Flower colour modification in transgenic Saintpaulia}

Depending on the variety, Saintpaulia flowers produce delphinidin-, cyanidin- and/or pelargonidin -based anthocyanins (Griesbach 1998, Tatsuzawa et al. 2012, Tatsuzawa and Hosokawa 2016). Cyanidinbased anthocyanins accumulate in the leaves of some varieties, imparting a deeper, but less green colour to the leaves (Arisumi 1967). Chalconebased flavonoids have been shown to be the yellow pigment present in yellow flowers (Deguchi et al. 2016).
Molecular analysis has shown that there are two distinct chalcone synthase (CHS) genes in the Saintpaulia genus, SaCHSA and SaCHSD (Caro et al. 2006). CHS codes for the first enzyme in the flavonoid production pathway. Using phylogenetic analysis, the CHS genes have been used to differentiate several Saintpaulia species $[S$. grandifolia (S. ionantha ssp. grandifolia), $S$. grotei (S. ionantha ssp. grotei), S. intermedia (S. ionantha ssp. pendula (B.L. Burtt) I. Darbysh. TSN 832528), S. ionantha and $S$. orbicularis (S. ionantha ssp. orbicularis (B.L. Burtt) I. Darbysh. TSN 832596] (Caro et al. 2006). Jiao et al. (2014) cloned the flavonoid 3',5'-hydroxylase $\left(F 3^{\prime} 5^{\prime} H\right)$ gene from $S$. ionantha (cultivar not indicated) and found maximum homology among $S$. ionantha cultivars, and also with Antirrhinum kelleggii and Torenia hybrida. Sense $F 3^{\prime} 5^{\prime} H$ expression vectors were transformed into tobacco using A. tumefaciens strain LBA4404. In transgenic tobacco, the flavonoid content detected using HPLC was 4.0$16.3 \%$ higher than that in the wild type $(1.76 \%)$, and flowers were light purple.

Despite the large palette of colours available amongst African violet varieties, there are still colour modifications that would be very valuable 
in Saintpaulia and which can only be achieved through genetic engineering. Broadly, the first strategy would be to increase the colour range in a single, very high quality variety, as was done using genetic engineering in torenia (Nishihara et al. 2013). The second strategy would be to use genetic engineering for the generation of colours not found in the species, such as a true red (van Schaik and Newlands 1963) or deep yellow. Aside from an undetailed report of a European field trial in 2001 (Cadic and Widehem 2001), flower colour modification by genetic engineering has not yet been demonstrated in Saintpaulia, although there are multiple theoretical avenues for flower colour modification in this genus, as illustrated in Figure 2. In summary, avenues that may be explored alone or in combination are:

- In white-flowered varieties, including coloured varieties in which the anthocyanin pathway has been down-regulated, transfer of betalain pigment biosynthesis genes for the production of novel yellow aurone-based pigments (Ono et al. 2006).

- Up and/or down regulation of the flavonoid hydroxylase genes on the existing anthocyanin pathway to alter the type and/ or ratio of anthocyanins accumulated. As an example of such a strategy, to produce a 'true red' variety, the anthocyanin pathway could be manipulated to produce varieties that only accumulate red cyanidin-based anthocyanins.

- Manipulation (through methylation or glycosylation) of the secondary structure moieties of existing anthocyanins to alter spectral qualities and thus flower colour (Tatsuzawa and Hosokawa 2016).

- Down-regulation of endogenous chalcone synthase genes to block anthocyanin biosynthesis. With suitable promoters this strategy could also be used to alter leaf colour by inhibiting anthocyanin accumulation in the leaves of affected varieties.

\section{CONCLUSIONS}

Radiation- or colchicine-induced mutagenesis has served as a useful tool to broaden genetic diversity in African violet, a vegetatively propagated ornamental species. As described in several papers in this review, at the research level mutation breeding and tissue-culture induced somaclonal variation have led to several changes in African violet plant architecture, including petiole length, surface area, flower diameter, inflorescence height and number of leaves and inflorescences per plant. Several economically desirable traits such as flower colour pattern, chlorophyll chimerism and dwarfing have also been observed in African violet using radiation and chemical mutagens. These traits can be stably propagated through vegetative means, including leaf culture (Teixeira da Silva et al. 2016a). African violet plants are very sensitive to alteration in light intensity, temperature, and humidity, and minor changes can lead to the development of leaf spot disease (Yun et al. 1997, Yang et al. 2001, Chen and Henny 2009). Plants resistant to biotic and abiotic stresses will need to be developed using transgenic strategies, and this requires robust and reproducible genetic engineering and tissue culture protocols to regenerate transformants. These techniques are now available. Agrobacterium-mediated genetic transformation has been shown to alter Saintpaulia genetic makeup by the introduction of a glucanase-chitinase gene (Ram and Mohandas 2003). Transformants with improved tolerance to boron stress have also been obtained (Ye et al. 2014). Genetic modification is also a tool that can be used to generate novel flower colours in Saintpaulia. However, to date, transgenic varieties of African violet have not been commercialised. Given the complexity of the regulatory processes associated with the release of transgenic plants, our expectation is that conventional breeding methods, including mutagenesis, will thus continue to dominate the product pipeline for African violet. The conservation of wild Saintpaulia species will continue to be a priority, and the best way to achieve this is through in vitro propagation (Teixeira da Silva et al. 2017). Molecular methods to classify germplasm (Teixeira da Silva et al. 2007) will need to be developed for African violet. To date, the use of 5S nuclear ribosomal DNA non-transcribed spacer sequences or internal transcribed spacer sequences to clearly differentiate Saintpaulia species in conservation studies (Möller and Cronk 1997, Lindqvist and Albert 1999, 2001) allows germplasm to be accurately classified, propagated and preserved.

\section{ACKNOWLEDGEMENT}

We are thankful to Ravi R. Sonani and Mafatlal M. Kher, Sardar Patel University, and Sylvia DeMar, Managing Editor, American Society for Horticultural Science, for providing difficult-toaccess literature. We also thank Mafatlal M. Kher 
for some useful suggestions about the review structure in an earlier draft.

\section{AUTHOR CONTRIBUTIONS}

The authors contributed equally to all aspects of review development and writing.

\section{CONFLICT OF INTEREST}

Authors declare no conflict of interest.

\section{REFERENCES}

Adisorn C., 2004. Lesson operating cytogenetic in agriculture. Department of Horticulture, Chiang Mai University, Thailand.

Afkhami-Sarvestani R., Serek M., Winkelmann T., 2012a. Interspecific crosses within the Streptocarpus subgenus Streptocarpella and intergeneric crosses between Streptocarpella and Saintpaulia ionantha genotypes. Sci. Hortic. 148: 215-222.

Afkhami-Sarvestani R., Serek M., Winkelmann T., 2012b. Protoplast isolation and culture from Streptocarpus, followed by fusion with Saintpaulia ionantha protoplasts. Eur. J. Hortic. Sci. 77: 249-260.

Ahloowalia B.S., Maluszynski M., 2001. Induced mutations - a new paradigm in plant breeding. Euphytica 118: 167-173.

ANONYMOUS., 2002. Saintpaulia self-pollination. African Violet Mag. 55(6): 39.

ARISUmi T., 1967. Dominant gene for anthocyanin in the leaf-blades of African violets. J. Hered. 58: 259-261.

ARISUmi T., 1964. Interspecific hybridization in African violets. J. Hered. 55: 181-183.

Arisumi T., Frazier L.C., 1968. Cytological and morphological evidence for the single-cell origin of vegetatively propagated shoots in thirteen species of Saintpaulia treated with colchicine. Proc. Am. Soc. Hortic. Sci. 93: 679-685.

BAATVIK S.T., 1993.ThegenusSaintpaulia(Gesneriaceae) 100 years: History, taxonomy, ecology, distribution and conservation. Fragm. Flor. Geobot. Suppl. 2: 97112.

Bhaskaran S., Smith R.H., Finer J.J., 1983. Ribulose bisphosphate carboxylase activity in anther-derived plants of Saintpaulia ionantha Wendl. Shag. Plant Physiol. 73: 639-642.

Bourgis F., Guyot R., Gherbi H., Tailliez E., Amabile I., Salse J., Lorieux M., Delseny M., Ghesquière A., 2008. Characterization of the major fragrance gene from an aromatic japonica rice and analysis of its diversity in Asian cultivated rice. Theor. Appl. Genet. 117: 353-68.

Broertjes C., 1974. Production of polyploids by the adventitious bud technique. In: Polyploid and Induced Mutations in Plant Breeding, International Atomic Energy Agency, Vienna, PL-503(6): 29-34.
Broertjes C., 1972. Use in plant breeding of acute, chronic or fractionated doses of X-rays or fast neutrons as illustrated with leaves of Saintpaulia. In: Agriculture Research Report-776. Centre for Agricultural Publishing and Documentation, Pudoc, Wageningen: 74.

Broertjes C., 1971. Dose-fractionation studies and radiation-induced protection phenomena in African violet. In: Survival of Food Crops and Livestock in the Event of a Nuclear War. D.W. Benson and A.H. Sparrow (eds), Proc. Symp. Brookhaven Natl. Lab. Upton, 1970, U.S. Atomic Energy Commission, Oak Ridge, Tennessee: 325-342.

Broertjes C., 1968. Mutation breeding of vegetatively propagated crops. Proc. $5^{\text {th }}$ Eucarpia Congress, Milan: 139-165.

Broertjes C., van Harten A.M., 1988. Applied Mutation Breeding for Vegetatively Propagated Crops. Elsevier, Amsterdam: 345.

Cadic A., Widehem C., 2001. Breeding goals for new ornamentals. Acta Hort. 552: 75-86.

Caro S.E., Stampfle J.M., Greene M.J., Kotarski M.A., 2006. Using a chalcone synthase gene to infer phylogenies in the genus Saintpaulia. Bios 77: 72-76.

CharlesworthD., Charlesworth B., 1987. Inbreeding depression and its evolutionary consequences. Ann. Rev. Ecol. Syst. 18: 237-268.

Chen J., Henny R.J., 2009. Cultural guidelines for commercial production of African violets (Saintpaulia ionantha) ENH 1096. Environmental Horticulture Department, Florida Cooperative Extension Service, Institute of Food and Agricultural Sciences, University of Florida, USA: 1-4.

Clayberg C.D., 1961. Hybridizing with the African violet species. African Violet Mag. 15: 105-107.

Datta S.K., Teixeira da Silva J.A., 2006. Role of induced mutagenesis for development of new flower colour and type in ornamentals. In: Floriculture, Ornamental and Plant Biotechnology: Advances and Topical Issues ( $1^{\text {st }}$ Edn.), Chapter 71, Volume I. J.A. Teixeira da Silva (ed.), Global Science Books, Ltd., Isleworth, UK: 640-645.

Deguchi A., Ohno S., Tatsuzawa F., Dio M., Hosokawa M., 2016. Identification of the yellow pigments in Saintpaulia flowers. Hort. Res. 15: 123-128.

DunCan R.R., 1997. Tissue culture-induced variation and crop improvement. In: Advances in Agronomy (Vol. 58). D.L. Sparks (ed.), Academic Press, London: 201-210.

Eastwood A., Bytebier B., Tye H., Tye A., Robertson A., Maunder M., 1998. The conservation status of Saintpaulia. Curtis's Bot. Mag. 15: 49-62.

EhrLich H., 1956. Cytological studies in Saintpaulia Wendl. (Gesneriacea) [sic]. Ph.D. thesis. University of Minnesota, USA.

Ehrlich H., 1958. Cytological studies in Saintpaulia Wendl. (Gesneriaceae). Am. J. Bot. 45: 177-182. 
EsPINo F.J., VAZQUEZ A.M., 1981. Chromosome numbers of Saintpaulia ionantha plantlets regenerated from leaves cultured in vitro with caffeine and colchicine. Euphytica 30: 847-853.

FarJadi-Shakib M., Mousavi A., Naderi R., 2012. Optimization of chromosomal preparation and cytological analysis of in vitro cultured African violet (Saintpaulia ionantha Wendl.). Acta Hort. 937: 917-922.

Gaj M., GaJ M.D., 1996. The high frequency of variegated forms after in vitro mutagenesis in Saintpaulia ionantha Wendl. Acta Soc. Bot. Pol. 65: 339-343.

GeIER T., 1983. Induction and selection of mutants in tissue cultures of Gesneriaceae. Acta Hort. 131: 329338.

Ghorbanzade Z., Ahmadabadi M., 2015. Stable transformation of the Saintpaulia ionantha by particle bombardment. Iran J. Biotechnol. 13: 11-16.

GoIdANichG.,GARAVINIC., 1959.MortalitàdiSaintpaulia jonantha [sic] per infestazione di Melodogyne arenaria Thamesii. Riv. Ortoflorofrutticoltura Ital. 23: 81-86.

GRIESBACH R.J., 1998. Flavonoids in Saintpauliaionantha expressing the fantasy mutation. Phytochemistry 48 : 829-830.

GRUNEWALDT J., 1983. In vitro mutagenesis of Saintpaulia and Pelargonium cultivars. Acta Hort. 131: 339-344.

Harrison C.J., Möller M., Cronk Q.C.B., 1999. Evolution and development of floral diversity in Streptocarpus and Saintpaulia. Ann. Bot. 84: 49-60.

Huang J., Zhang K., Shen Y., Huang Z., Li M., Tang D., ET AL., 2009. Identification of a high frequency transposon induced by tissue culture, nDaiZ, a member of the $h A T$ family in rice. Genomics 93: 274-281.

Hunter R.S., 1948. Photoelectric color-difference meter. J. Optical Soc. Amer. 38: 661.

Itis -Integrated TAxonomic Information System. Available online at https://www.itis.gov/; cited on 20 May 2017.

JAIN S.M., 1993a. Somaclonal variation in Begonia $\times$ elatior and Saintpaulia ionantha L. Sci. Hort. 54: 221-231.

JAIN S.M., 1993b. Studies on somaclonal variation in ornamental plants. Acta Hort. 336: 365-372.

JAIN S.M., 1997a. Micropropagation of selected somaclones of Begonia and Saintpaulia. J. Biosci. 22: 585-592.

JAIN S.M., 1997b. Creation of variability by mutation and tissue culture for improving plants. Acta Hort. 447: 69-77.

JensSON L.K., BARRETT S.C.H., 2002. Solving the puzzle of mirror-image flowers. Nature 417: 707.

Jiao Y., Chen J., Jia H.Y., Zhang K., Yang K., 2014. Cloning of flavonoid-3'5'-hydroxylase gene in Saintpaulia ionantha and expression analysis of transgenic Nicotiana tabacum. J. Beijing Univ. Agric. 29: 11-13.

KaepPler S.M.,KAePplerH.F., RheeY.,2000.Epigenetic aspects of somaclonal variation in plants. Plant Mol. Biol. 43: 179-188.

Kelly J.W., Lineberger R.D., 1981. Thermal neutron induced changes in Saintpaulia. Environ. Exp. Bot. 21: 95-102.

Kolehmainen J., Korpelainen H., Mutikainen P., 2010. Inbreeding and inbreeding depression in a threathened endemic plant, the African violet (Saintpaulia ionantha ssp. grotei), of the East Usambara Mountains, Tanzania. Afr. J. Ecol. 48: 576-587.

Kolehmainen J., Mutikainen P., 2006. Reproductive ecology of three endangered African violet (Saintpaulia H. Wendl.) species in the East Usambara Mountains, Tanzania. Afr. J. Ecol. 44: 219-227.

Kondo E., Nakayama M., Kameari N., Tanikawa N., Morita Y., Akita Y., Hase Y., TanaKa A., Ishizaka H., 2009. Red-purple flower due to delphinidin 3,5-diglucoside, a novel pigment for Cyclamen spp., generated by ion-beam irradiation. Plant Biotechnol. 26: 565-569.

KrishnaH.,AlizadehM.,SinghD.,SinghU.,Chauhan N., Eftekhari M., SADH R.H., 2016. Somaclonal variations and their applications in horticultural crops improvement. 3 Biotech. 6(1): 54.

KushikawaS.,Hoshino Y.,MirM.,2001.Agrobacteriummediated transformation of Saintpaulia ionantha Wendl. Plant Sci. 161: 953-960.

Kushikawa S., Miyoshi K., Mir M., 2002. Pre-culture treatment enhances transient GUS gene expression in leaf segment of Saintpaulia ionantha Wendl. after inoculation with Agrobacterium tumefaciens. Plant Biotechnol. 19: 149-152.

LARKINP.J.,SCOWCROFT W.R., 1981.Somaclonalvariation - a novel source of variability from cell cultures for plant improvement. Theor. Appl. Genet. 60: 197-214.

Lindqvist C., Albert V.A., 1999. Phylogeny and conservation of African violets (Saintpaulia; Gesneriaceae): New findings based on nuclear ribosomal 5S non-transcribed spacer sequences. Kew Bull. 54: 363-377.

Lindqvist C., Albert V.A., 2001. A high elevation ancestry for the Usambara Mountains and lowland populations of African violets (Saintpaulia, Gesneriaceae). Syst. Geogr. Plants 71: 37-44.

Lineberger R.D., Druckenbrod M., 1985. Chimeral nature of the pinwheel flowering African violets (Saintpaulia, Gesneriaceae). Am. J. Bot. 72: 12041212.

Loureiro J., RodriguezE., DoležEl J., SAntos C., 2007. Two new nuclear isolation buffers for plant DNA flow cytometry: a test with 37 species. Ann. Bot. 100(4): 875-888.

Matsuda S., Sato M., Ohno S., Yang S.J., Doi M., Hosokawa J., 2014. Cutting leaves and plant growth 
regulator application enhance somaclonal variation induced by transposition of VGs1 of Saintpaulia. J. Jpn. Soc. Hortic. Sci. 83: 308-316.

Mercuri A., De Benedetti L., Burchi G., Schiva T., 2000. Agrobacterium-mediated transformation of African violet. Plant Cell Tiss. Org. Cult. 60: 39-46.

Möller M., Cronk Q.C.B., 1997. Phylogeny and disjunct distribution: evolution of Saintpaulia (Gesneriaceae). Proc. Royal Soc. London B: Biol. Sci. 264: 1827-1836.

Nishihara M., Shimoda T., Nakatsuka T., Arimura G. 2013. Frontiers of torenia research: innovative ornamental traits and study of ecological interaction networks through genetic engineering. Plant Methods 9: 23.

Ohкi S., Наshimoto Y., Ohno M., 2009. Preliminary report on Agrobacterium-mediated genetic transformation of Begonia rex and Saintpaulia spp. Acta Hort. 829: 345-348.

Ono E., Fukuchi-Mizutani M., Nakamura N., Fukui Y., Yonekura-Sakakibara K., Yamaguchi M., Nakayama T., Tanaka T., Kusumi T., Tanaka Y., 2006. Yellow flowers generated by expression of the aurone biosynthetic pathway. Proc. Nat. Acad. Sci. USA 103: 11075-11080.

Paek K.Y., Hahn E.J., 1999. Variations in African violet 'Crimson Frost' micropropagated by homogenized leaf tissue culture. HortTechnology 9: 625-629.

Pei R.J., Chen X.Q., Sun N., Zhang N.N., Liu Y., LiU F.H., 2012. Petal cell $\mathrm{pH}$ value determination and F3'5'H gene fragment cloning of Saintpaulia ionantha. J. Tianjin Agri. Univ. 19: 11-14.

Ram M.S.N., Mohandas S., 2003. Transformation of African violet (Saintpaulia ionantha) with glucanase-chitinase genes using Agrobacterium tumefaciens. Acta Hort. 624: 471-478.

SahiJram L., 2014. Modifying DNA methylation pattern in embryos for application in horticultural crop improvement. In: Horticulture for Inclusive Growth, Westville Publishing House, New Delhi: 504-521.

SAHIJRAM L., 2015. Somaclonal variation in micropropagated plants. In: Plant Biology and Biotechnology (Vol. II) Plant Genomics and Biotechnology. B. Bahadur, M.V. Rajam, L. Sahijram, K.V. Krishnamurthy (eds), Springer, Heidelberg, Germany: 407-416.

Samanta M.K., Dey A., Gayen S., 2016. CRISP/Cas9: an advanced tool for editing plant genomes. Transgenic Res. 25: 561-573.

Sato M., Hosokawa M., Doi M. 2011a. Somaclonal variation is induced de novo via the tissue culture process: A study quantifying mutated cells in Saintapulia. PLoS ONE 6: e23541.

SatoM.,KawabeT.,HosokawaM., TatsuZawaF.,DoiM., 2011b. Tissue culture-induced flower-color changes in Saintpaulia caused by excision of the transposon inserted in the flavonoid 3', 5' hydroxylase (F3'5' $H$ ) promoter. Plant Cell Rep. 30: 929-939.
SeneviratneK.A.C.N, WiJesundaraD.S.A., 2003.New African violets (Saintpaulia ionantha $\mathrm{H}$. Wendl.) induced by colchicine. Curr. Sci. 87: 138-140.

SeneviratneK.A.C.N., WiJesundaraD.S.A.,2007.First African violets (Saintpaulia ionantha H. Wendl.) with a changing colour pattern induced by mutation. Am. J. Plant Physiol. 2: 233-236.

Shajiee K., Tehranifar A., Naderi R., Khalighi A., 2006. Somaclonal variation induced de novo leaf chimeric mutants during in vitro propagation of African violet (Saintpaulia ionantha Wendl.). Acta Hort. 725: 337-340.

Skog L.E., Boggan J.K., 2010. World checklist of Gesneriaceae. Washington, DC: Dept. of Botany, Smithsonian Institution.

Sparrow A.H., Sparrow R.C., Schairer L.A., 1960. The use of X-rays to induce somatic mutations in Saintpaulia. African Violet Mag. 13: 32-37.

Stewart D., Graciet E., Wellmer F., 2016. Molecular and regulatory mechanisms controlling floral organ development. FEBS J. 283: 1823-1830.

SugIURA T., 1936. Studies on the chromosome numbers in higher plants, with special reference to cytokinesis. Cytologia (Tokyo) 7: 544-595.

Sun Y.J., Chen X.Q., Sun N., Chen J., Zhang L., 2010. Karyotype analysis of Saintpaulia ionantha. J. Tianjin Agri. Univ. 17: 5-8.

Tatsuzawa F., Hosokawa M., 2016. Flower colors and their anthocyanins in Saintpaulia cultivars (Gesneriaceae). Hort. J. 85: 63-69.

Tatsuzawa F., Hosokawa M., Saito N., Honda T., 2012. Three acylated anthocyanins and a flavone glycoside in violet-blue flowers of Saintpaulia 'Thamires'. S. Afr. J. Bot. 79: 71-76.

Teixeira dA Silva J.A., BoliboK H., RakoczyTrojAnOwsKA M., 2007. Molecular markers in micropropagation, tissue culture and in vitro plant research. Genes, Genomes Genomics 1(1): 66-72.

Teixeira da Silva J.A., Dewir Y.H., WiCaksono A., Kher M.M., Kim H.H., HosoKawa M., Zeng S., 2016a. Morphogenesis and developmental biology of African violet (Saintpaulia ionantha H. Wendl). J. Plant Dev. 23: 15-25.

Teixeira da Silva J.A., Dobránszki J., Cardoso J.C., Chandler S.F., Zeng S.J., 2016b. Review: Methods for genetic transformation in Dendrobium. Plant Cell Rep. 35: 483-504.

Teixeira da Silva J.A., Zeng S.J., Wicaksono A., Kher M.M., KIm H.-H., HosoKawa M., DewIR Y.S., 2017. In vitro propagation of African violet: a review. S. Afr. J. Bot. (in press) DOI: 10.1016/j.sajb.2017.05.018

The Plant List, 2017. Saintpaulia. Available online at: http://www.theplantlist.org/tpl1.1/search?q=Saintpaulia; cited on 20 May 2017.

Tsukamoto Y., Maekawa S., Yamamoto K., Sasaki M., 1982. Saintpaulia. Bunka Publishing, Tokyo, Japan. 
VAN HARTEN A.M., 2007. Mutation Breeding: Theory and Practical Applications. Cambridge University Press, Cambridge, UK: 368.

van Schaik N.W., Newlands G., 1963. The problem of breeding a red African violet. S. Afr. J. Sci. 59: 5558.

VAzquez A.M., DAVey M.R., Short K.C., 1977. Organogenesis in culture of Saintpaulia ionantha. Acta Hort. 78: 249-258.

Vogel S., 1978. Evolutionary shifts from reward to deception in pollen flowers. In: The Pollination of Flowers by Insects. A. Richards (ed.), Linn. Soc. Sym. Ser., Academic Press, London: 89-96.

WANG L., GAO Q., WANG Y.Z., LIN Q.B., 2006. Isolation and sequence analysis of two $C Y C$-like genes, SiCYC1A and SiCYC1B, from zygomorphic and actinomorphic cultivars of Saintpaulia ionantha (Gesneriaceae). Acta Phytotax. Sin. 44: 353-361.

WARFIELD D., 1973. Induction of mutations in African violet (Saintpaulia ionantha Wendl.) by ethylmethanesulfonate. HortScience 8: 29.

Winkelmann T., GrunewaldT J., 1995. Analysis of protoplast-derived plants of Saintpaulia ionantha $\mathrm{H}$ Wendl. Plant Breeding 114: 346-350.

Wongpiyasatid A., Jompuk P., Chusreeaeom K., TAYCHASINPITAK T., 2007a. Effects of chronic gamma irradiation on adventitious plantlet formation of Saintpaulia ionantha (African violet) detached leaves. Kasetsart J. Nat. Sci. 41: 414-419.

Wongpiyasatid A., ThinnoK T., Taychasinpitak T., Jompuk P., Chusreeaeom K., Lamseejan S., 2007 b. Effects of acute gamma irradiation on adventitious plantlet regeneration and mutation from leaf cuttings of African violet (Saintpaulia ionantha). Kasetsart J. Nat. Sci. 41: 633-640.

Yang S.J., Hosokawa M., Hayashi T., Yazawa S., 2003. Wounding enhances rapid-browning responsiveness of distal unwounded leaves to water stimulus in
Ruellia macrantha. J. Jpn. Soc. Hort. Sci. 72: 286291.

Yang S.J., Hosokawa M., Hayashi T., Yazawa S., 2002. Leaf browning induced at sites distant from wounds in Acanthaceae and Gesneriaceae plants. J. Jpn. Soc. Hort. Sci. 71: 535-537.

Yang S.J., Hosokawa M., Mizuta Y., Yun J.G., Mano J., YAZAWA S., 2001. Antioxidant capacity is correlated with susceptibility to leaf spot caused by a rapid temperature drop in Saintpaulia (African violet). Sci. Hort. 88: 59-69.

Yang S.J., Kitamura Y., Hosokawa M., Yazawa S., 2006. Low temperature sensitivity enhanced by local wounding in Saintpaulia. J. Jpn. Soc. Hortic. Sci. 75: 476-480.

Ye Z.Q., Li J.H., WANG G.D., 2014. Agrobacteriummediated genetic transformation of AtTIP5;1 gene into Saintpaulia ionantha. Acta Bot. Occident. Sin. 34: 2412-2417.

Yu W., Yau Y.Y., Birchler J.A., 2016. Plant artificial chromsome technology and its potential application in genetic engineering. Plant Biotech. J. 14: 11751182.

Yun J.G., HaYAshi T., Yazawa S., 1997. Diurnal changes in leaf spot sensitivity of Saintpaulia (African violet). Sci. Hortic. 70: 179-186.

Zhou L.B., Li W.J., Ma S., Dong X.C., Yu L.X., Li Q., Zhou G.M., Gao Q.X., 2006a. Effects of ion beam irradiation on adventitious shoot regeneration from in vitro leaf explants of Saintpaulia ionahta [sic]. Nucl Instr. Methods Phys. Res. Sect. B 244: 349-353.

Zhou L.B., Li W.J., Ma S., Dong X.C., Li Q., GaO Q.X., 2006b. Effects of X-ray and electron beam irradiation on adventitious bud regeneration from in vitro leaf explants of Saintpaulia ionahta [sic]. J. Radiat. Res. Radiat. Process 24: 53-58.

Received January 13, 2017; accepted May 23, 2017 